\title{
LITERASI MEMBACA ANAK-ANAK DI PESISIR PANTAI SAWARNA, LEBAK BANTEN
}

\author{
Suraya $^{1}$, Agustina Zubair ${ }^{2}$, Diah Wardhani ${ }^{3}$ \\ IImu Komunikasi, Universitas Mercu Buana Jakarta \\ Diterima 19 Februari 2019 / Disetujui 29 Maret 2019
}

\begin{abstract}
This community empowerment activity is in the form of training on the socialization of Reading Literacy to Students in Sawarna Beach, Lebak banten. The purpose of this training the students and school-aged children have the ability to read and become accustomed to reading. This training activity was held on February 13 , 2018 in Sawarna Village, Lebak Banten. This activity is followed by students who are domiciled in the village. The participants have not fully read the habit either at home or at school. The lack of facilities for children's story books owned by schools and at home. Children or Students Kindergarten requires motivation and inspiration about activities and reading habits or reading literacy.
\end{abstract}

Keywords : Reading Literacy, Kids, Empowerment Activity

\begin{abstract}
ABSTRAK
Kegiatan pengabdian masyarakat ini berbentuk pelatihan mengenai sosialisasi Literasi Membaca pada Siswa/i di Pesisir Sawarna, Lebak banten. Tujuan pelatihan ini para siswa dan anak usia sekolah memiliki kemampuan membaca dan menjadi terbiasa membaca. Kegiatan pelatihan ini diadakan bulan 13 Februari 2018 di Desa Sawarna, Lebak Banten. Kegiatan ini diikuti oleh para siswa/i yang berdomisili di desa tersebut. Para peserta belum sepenuhnya memiliki kebiasaan membaca baik di rumah maupun di sekolah. Minimnya fasilitas bukubuku cerita anak-anak yang dimiliki sekolah maupun di rumah. Anak-anak atau Siswa/i TK membutuhkan motivasi dan inspirasi mengenai kegiatan dan pembiasaan membaca atau literasi membaca.
\end{abstract}

Kata Kunci : Literasi Membaca, Anak-anak, Kegiatan pemberdayaan

\footnotetext{
*Korespondensi Penulis:

e-mail: suraya.suraya@mercubuana.ac.id
} 


\section{PENDAHULUAN}

Kawasan Lebak secara geografis terletak pada posisi antara 105 25'-106 30' Bujur Timur dan 6 18'-7 00' Lintang Selatan. Peta topografi lembar Balaraja, Sheet 4224 II, Series T 725, menunjukkan bahwa kontur tanah di kawasan Lebak adalah datar bergelombang dengan variasi ketinggian antara 0-100 m dpl. Ketinggian antara 0-200 m dpl berada di kawasan pantai, yaitu Lebak bagian selatan, ketinggian antara 201-500 m dpl terletak di bagian pinggang bukit, ketinggian 501-100 m dpl umumnya berada di lerenga bagian tengah bukit sampai ke puncak. Pegunungan Kendeng menjadi pembelah antara Lebak bagian utara dan Lebak bagian selatan. Adapun secara geografis kawasan Lebak sebalah utara dibatasi oleh Kabupaten Serang, sebelah barat Kabupaten Pandeglang, sebelah timur Provinsi Jawa Barat, dan sebelah selatan Samudra Hindia.

\section{Komisi Perlindungan Anak} Indonesia (KPAI) telah melakukan pengawasan tentang penanganan anak korban bencana gempa bumi di barat daya Kabupaten Lebak, Banten. Gempa bumi yang bermagnitudo 6,1 skala Richter terjadi pada Selasa, 23 Januari 2018 tersebut, diikuti sebanyak 53 gempa susulan. Terkait bencana alam di Kabupaten Lebak, Banten, Komisioner Bidang Sosial dan Anak dalam Situasi Darurat KPAI, Susianah Affandy menyampaikan beberapa hal. KPAI akan terus melakukan pengawasan terhadap pemenuhan hak anak atas sekolah atau madrasah darurat di lokasi bencana selama situasi darurat, hingga tersedianya tersedianya ruangan belajar. Karena, saat ini gedung sekolah tersebut tak bisa difungsikan akibat gempa.

"Penyelenggaraan

sekolah/

madrasah aman bencana yang akan menjadi lokus pengawasan KPAI meliputi antara lain terintegrasinya antarjenjang pendidikan dan/atau antarjenis pendidikan, penyelenggaraan pendidikan formal atau nonformal dengan cara menyesuaikan waktu, tempat, sarana dan prasarana pembelajaran, pendidik dan tenaga kependidikan, bentuk, program dan/atau sumber daya pembelajaran lainnya dengan kondisi kesulitan peserta didik," katanya. Selain sekolah/madrasah aman bencana, KPAI juga mendorong pemerintah daerah menyelenggarakan kegiatan psikosial bagi anak-anak korban bencana yang meliputi penyelenggaraan kegiatan trauma healing (KPAI.go.id, 2018). $\quad$ http://www.kpai.go.id/berita/kpaidesak-pemerintah-bangun-sekolah-darurat-dilebak-banten/

Pemerintah Kabupaten Serang bersama seluruh elemen masyarakat mendeklarasikan gerakan budaya membaca. Gerakan ini akan secara konsisten mendorong peningkatan keterampilan dan kecerdasan literasi pelajar di Serang melalui gerakan budaya membaca, mulai dari tingkat SD/MI, SMP /MTS dan SMA/MA/SMK. Demikian seruan Wakil Bupati Serang Pandji Tirtayasa usai memimpin upacara bendera dalam rangka peringatan hari pendidikan nasional (Hardiknas) di Alun-alun Kabupaten Serang, Senin, 2 Mei 2016. Usai membacakan deklarasi tersebut, Pandji Tirtayasa menandai gerakan tersebut dengan membaca senyap bersama-sama selama lima belas menit. Seluruh hadirin yang didominasi guru dan siswa serta jajaran dinas pendidikan serempak mengambil buku yang berada di sekitar mereka dan mulai membaca. "Kegiatan membaca senyap dilakukan agar peserta didik dan segenap warga terbiasa untuk membaca. Karena bagaimana pun membaca merupakan gerbang pengetahuan. Pembiasaan ini akan memunculkan budaya literasi yang kita harapkan," kata Rifki Rosyad, Koordinator Provinsi USAID Prioritas.

Rifki Rosyad pada kesempatan tersebut menyerahkan secara simbolis paket buku bacaan berjenjang kepada Wabup Serang. Untuk kabupaten Serang, 
USAID PRIORITAS akan menghibahkan 88.740 paket buku ke 145 sekolah. Penggunaan buku bacaan berjenjang ini pun melibatkan fasilitator daerah khusus buku bacaan berjenjang yang sudah dilatihkan. Tercatat di Kabupaten Serang ada 8 fasilitator program buku bacaan berjenjang yang akan melatihkan penggunaan buku tersebut. Wabup Serang juga menyempatkan berkunjung ke lokasi pameran USAID Prioritas. "Saya senang siswa suka membaca buku bacaan seperti novel. Menurut saya, saat siswa membaca buku kesukaan tentu siswa terpacu untuk membaca buku pelajaran lebih mudah," ujarnya.(dhe/a3) (Tirtayasa, 2016)

https://bantenday.com/pandjitirtayasa-deklarasikan-budaya-membaca/

Pendidikan Pra sekolah
atau disebut Pendidikan Anak Usia Dini (PAUD) diatur dalam Undang undang No. 6 tahun 2003 tentang Sistem Pendidikan Nasional. Sehingga dalam pelaksanaannya banyak lembaga pendidikan berdiri dalam rangka mencerdaskan anak bangsa. Namun jika tidak ditunjang oleh pemerintah Daerah khususnya bantuan infrastruktur dan bantuan kelembagaan, maka yang terjadi pada lembaga tersebut akan berjalan seadanya bahkan jauh dari kata layak. Kekurangan fasilitas yang memadai dan infrastruktur bangunan yang buruk dialami oleh lembaga PAUD Attorik yang berlokasi di Kampung Gintung Desa Mekarjaya Kecamatan Panggarangan Kabupaten Lebak.

Ibu Adrian pengelola PAUD Attorik mengaku, dalam mengelola lembaga pendidikannya, dirinya cukup kewalahan lantaran hanya bermodalkan kemauan dan itikad baik untuk membantu warga masyarakat khususnya anak usia dini dalam mengembangkan serta mendidiknya. Chanelbanten.com, Jum'at (6/10/2017). Adrian menceritakan, dirinya sempat diusir ketika lembaga tersebut pinjam gedung sekolah ke madrasah ibtidaiyah gintung, namun berkat dukungan warga dirinya mengaku sekarang sudah punya gedung baru. "Walaupun sederhana, ataupun dari jenis asbes saya tetep optimis," katanya. Adrian mengharapkan uluran tangan dari Pemerintah Daerah Kabupaten Lebak khususnya bantuan infrastruktur sebagai sarana penunjang. "Saat ini saya sudah memiliki tiga lembaga pendidikan dikecamatan Panggarangan dengan jumlah murid ditiga lokasi sebanyak 80 siswa. Alhamdulillah tingkat partisipasi warga dalam menyekolahkan anakanaknya sangat tinggi," imbuhnya. (Abak) (Adrian, 2017) https://www.chanelbanten.com/2017/10/06/ini -kisah-guru-paud-yang-pernah-diusir-garagara-numpang-belajar/

Dari hasil survei UNESCO pun juga menunjukkan bahwa minat baca masyarakat yang paling rendah di ASEAN adalah Indonesia. Rendahnya minat baca ini dibuktikan dengan indeks membaca masyarakat Indonesia yang baru sekitar 0,001, artinya dari seribu penduduk, hanya ada satu orang yang masih memiliki minat baca tinggi. Permasalahan pendidikan yang dihadapi anak-anak usia dini dan sekolah dasar adalah selain fasilitas sekolah tetapi juga kualitas pendidikannya terutama kemampuan dan kebiasaan anak-anak membaca. Hal inilah yang diperlukan oleh siswa-siswa usia dini dan usia sekolah dasar di Sawarna Lebak Banten.

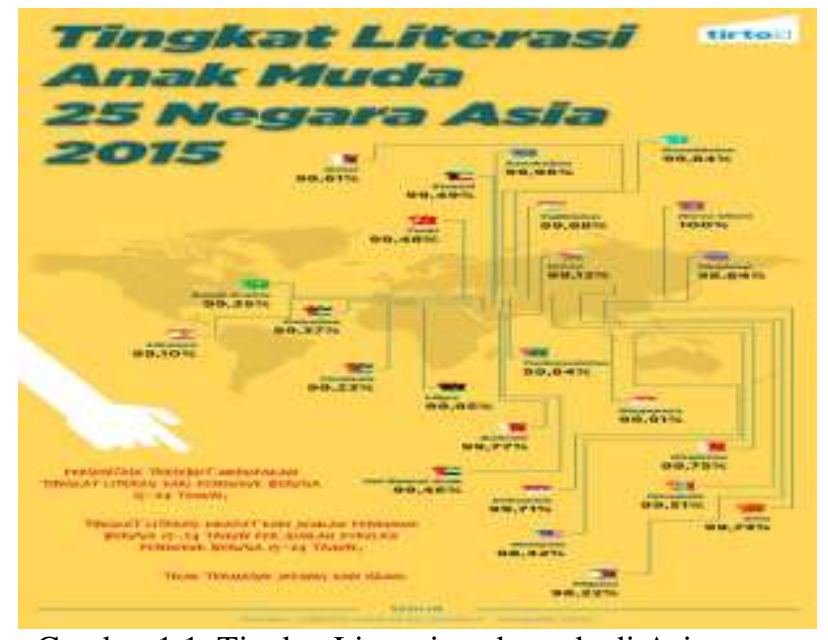

Gambar 1.1. Tingkat Literasi anak muda di Asia 
Sumber : (Tirto.id, 2016) https://tirto.id/tingkat$\underline{\text { literasi-anak-muda-asia-bHFT }}$

Kegiatan pengabdian masyarakat dengan memberikan sosialisasi literasi membaca siswa/i sekolah dasar di pesisir pantai Sawarna Banten ini bertujuan agar anak-anak memiliki kemampuan membaca dan terbiasa dengan kebiasaan membaca agar meningkatkan kecerdasan mereka. Kegiatan ini sesuai dengan apa yang telah dicanangkan oleh Kementrian Pendidikan dan Kebudayaan :

Menteri Pendidikan dan

Kebudayaan (Mendikbud) Anies

Baswedan meluncurkan Gerakan Literasi Sekolah "Bahasa Penumbuh Budi Pekerti". Peluncuran Gerakan Literasi Sekolah itu dilakukan secara simbolis dengan menyerahkan buku paket bacaan untuk 20 sekolah di DKI Jakarta sebagai bahan awal kegiatan literasi. Gerakan Literasi Sekolah dikembangkan berdasarkan Permendikbud Nomor 21 Tahun 2015 tentang Penumbuhan Budi Pekerti. Mendikbud mengatakan, Permendikbud tersebut adalah sebuah upaya untuk menumbuhkan budi pekerti anak. "Kata yang dipakai adalah 'penumbuh' karena kita hanya menumbuhkan, bukan menanamkan budi pekerti," katanya di sebuah hotel di Jakarta, Selasa malam (18/8/2015).

Sementara itu, Kepala Badan Pengembangan dan Pembinaan Bahasa Kemendikbud, Mahsun, mengatakan Gerakan Literasi Sekolah ini bertujuan membiasakan dan memotivasi siswa untuk mau membaca dan menulis guna menumbuhkan budi pekerti. Dalam jangka panjang, diharapkan dapat menghasilkan anak-anak yang memiliki kemampuan literasi tinggi. Karena itulah, buku-buku yang dibagikan untuk sekolah dalam Gerakan Literasi Sekolah ini adalah buku-buku yang dapat menumbuhkan budi pekerti. Buku yang dijadikan acuan sebagai bahan literasi di sekolah di antaranya buku cerita atau dongeng lokal, buku-buku yang menginspirasi seperti biografi tokoh lokal dan biografi anak bangsa yang berprestasi, buku-buku sejarah yang membentuk semangat kebangsaan atau cinta tanah air.

"Kegiatan literasi ini tidak hanya membaca, tetapi juga dilengkapi dengan kegiatan menulis yang harus dilandasi dengan keterampilan atau kiat untuk mengubah, meringkas, memodifikasi, menceritakan kembali, dan seterusnya," tutur Mahsun. Peluncuran Gerakan Literasi Sekolah dilaksanakan di sela-sela agenda Semiloka Kebahasaan Lembaga Adat yang digelar dalam rangka Peringatan 70 Tahun Hari Jadi Bahasa Negara. (Desliana Maulipaksi/Sumber: Badan Pengembangan dan Pembinaan Bahasa Kemendikbud) (Maulipaksi, 2015)

https://www.kemdikbud.go.id/main/blog/ 2015/08/mendikbud-luncurkan-gerakanliterasi-sekolah-4514-4514-4514

Membaca merupakan merupakan keterampilan berbahasa.dan faktor yang penting dalam proses pembelajaran, karena dengan membaca peserta didik dapat memperoleh informasi. Membaca merupakan salah satu kegiatan dalam berliterasi. Literasi tidak dapat dipisahkan dari dunia pendidikan. Literasi menjadi sarana peserta didik dalam mengenal, memahami, dan menerapkan ilmu yang didapatkannya di bangku sekolah.

Pada tingkat sekolah menengah (usia 15 tahun) pemahaman membaca peserta didik Indonesia (selain matematika dan sains) diuji oleh Organisasi untuk Kerja Sama dan 
Pembangunan Ekonomi (OECDOrganization for Economic Cooperation and Development) dalam Programme for International Student Assessment (PISA). Hasil penelitian yang dilakukan oleh PISA pada tahun 2012 menunjukkan peserta didik Indonesia berada pada peringkat ke-64 dari 65 negara yang turut bertasipasi dalam PISA dengan skor 396 (skor rata-rata OECD 496). Sedangkan hasil penelitian yang dilakukan pada tahun 2015 menunjukkan peserta didik Indonesia berada pada peringkat ke-62. Indonesia memperoleh skor 397 (skor rata-rata OECD 493). Pada penelitian tahun 2015 terdapat 70 negara yang turut berpartisipasi dalam PISA.

Selanjutnya, berdasarkan data yang diperoleh dari Badan Pusat Statistik angka melek huruf untuk golongan penduduk berumur 15-19 tahun pada tahun 2010 memiliki presentase sebesar 99.56\%, tahun 2011 sebesar 98.61\%, tahun 2012 sebesar $98.85 \%$, tahun 2013 sebesar 99.42\%, dan tahun 2014 99.67\%. Capaian tersebut sebenarnya menunjukkan bahwa Indonesia memiliki tingkat melek huruf yang tinggi. Namun, tantangan yang dihadapi saat ini adalah masih rendahnya minat baca. Jika dibandingkan oleh hasil penelitian yang dilakukan OECD, Indonesia selalu menempati urutan paling bawah. Pada penelitian tahun 2015, posisi Indonesia dibawah Vietnam yang menempati urutan ke-8 dan Thailand yang menempati urutan ke-54. Hal ini menjadi persoalan yang cukup serius bagi bangsa Indonesia dalam hal membaca khususnya, karena membaca merupakan dasar untuk memperoleh pengetahuan, keterampilan, dan pembentukan sikap peserta didik.

Permasalahan ini menuntut pemerintah untuk menciptakan strategi khusus untuk meningkatkan minat baca dan kemampuan membaca peserta didik. Implementasi strategi tersebut yaitu dengan menciptakan Gerakan Literasi Sekolah. Gerakan Literasi Sekolah mempunyai tujuan untuk membiasakan dan memotivasi peserta didik untuk mau membaca dan menulis guna menumbuhkan budi pekerti. Gerakan Literasi Sekolah memperkuat gerakan penumbuhan budi pekerti sebagaimana dituangkan dalam Peraturan Menteri Pendidikan dan Kebudayaan Nomor 23 Tahun 2015.

\section{A. Pengertian Literasi dan Gerakan Literasi Sekolah}

Kegiatan literasi selama ini identik dengan aktivitas membaca dan menulis. Namun, Deklarasi Praha pada tahun 2003 menyebutkan bahwa literasi juga mencakup bagaimana seseorang berkomunikasi dalam masyarakat. Literasi juga bermakna praktik dan hubungan sosial yang terkait dengan pengetahuan, bahasa, dan budaya (UNESCO, 2003). Deklarasi UNESCO itu juga menyebutkan bahwa literasi informasi terkait pula dengan kemampuan untuk mengidentifikasi, menentukan, menemukan, mengevaluasi, menciptakan secara efektif dan terorganisasi, menggunakan dan mengomunikasikan informasi untuk mengatasi berbagai persoalan. Kemampuan itu perlu dimiliki tiap individu sebagai syarat untuk berpartisipasi dalam masyarakat informasi, dan itu bagian dari hak dasar manusia menyangkut pembelajaran sepanjang hayat.

Sedangkan pengertian Literasi Sekolah dalam konteks Gerakan Literasi Sekolah adalah kemampuan mengakses, memahami, dan menggunakan sesuatu secara cerdas melalui berbagai aktivitas, antara lain membaca, melihat, menyimak, menulis, dan/atau berbicara. Gerakan Literasi Sekolah merupakan merupakan suatu usaha atau kegiatan yang bersifat partisipatif dengan melibatkan warga sekolah (peserta didik, guru, kepala sekolah, tenaga kependidikan, pengawas sekolah, Komite Sekolah, orang tua/wali murid peserta didik), akademisi, penerbit, 
media massa, masyarakat (tokoh masyarakat yang dapat merepresentasikan keteladanan, dunia usaha, dll.), dan pemangku kepentingan di bawah koordinasi Direktorat Jenderal Pendidikan Dasar dan Menengah Kementerian Pendidikan dan Kebudayaan.

Gerakan Literasi Sekolah adalah gerakan sosial dengan dukungan kolaboratif berbagai elemen. Upaya yang ditempuh untuk mewujudkannya berupa pembiasaan membaca peserta didik. Pembiasaan ini dilakukan dengan kegiatan 15 menit membaca (guru membacakan buku dan warga sekolah membaca dalam hati, yang disesuaikan dengan konteks atau target sekolah). Ketika pembiasaan membaca terbentuk, selanjutnya akan diarahkan ke tahap pengembangan, dan pembelajaran (disertai tagihan berdasarkan Kurikulum 2013). Variasi kegiatan dapat berupa perpaduan pengembangan keterampilan reseptif maupun produktif (Dirjen Pendidikan Dasar dan Menengah, 2016); (Kebudayaan, 2016); (Teguh, 2017).

Gerakan literasi sekolah juga telah diteliti, salah satunya Syaifur Rohman yang menkelaskan tentang budaya membaca pada anak melalui program gerakan literasi sekolah (Rahman, 2017). Selanjutnya Mulyo Teguh yang juga menjelaskan mengenai gerakan membaca pada siswa/si di sekolah dasar. menumbuhkembangkan budi pekerti peserta didik melalui pembudayaan ekosistem literasi sekolah agar mereka menjadi pembelajar sepanjang hayat (Dirjen Pendidikan Dasar dan Menengah, 2016); (Kebudayaan, 2016); (Teguh, 2017).

\section{B. Tujuan Gerakan Literasi Sekolah}

Gerakan Literasi Sekolah mempunyai dua tujuan, yaitu tujuan umum dan tujuan khusus. Tujuan Umum : Menumbuh kembangkan budi pekerti peserta didik melalui pembudayaan ekosistem literasi sekolah yang diwujudkan dalam Gerakan
Literasi Sekolah agar mereka menjadi pembelajar sepanjang hayat. Tujuan Khusus : (1) Menumbuhkembangkan budaya literasi di sekolah. Meningkatkan kapasitas warga dan lingkungan sekolah agar literat. (3) Menjadikan sekolah sebagai taman belajar yang menyenangkan dan ramah anak agar warga sekolah mampu mengelola pengetahuan. Menjaga keberlanjutan pembelajaran dengan menghadirkan beragam buku bacaan dan mewadahi berbagai strategi membaca (Dirjen Pendidikan Dasar dan Menengah, 2016); (Kebudayaan, 2016); (Teguh, 2017)

\section{Komponen Literasi}

Komponen literasi informasi terdiri atas literasi dini, literasi dasar, literasi perpustakaan, literasi media, literasi teknologi, dan literasi visual. Dalam konteks Indonesia, literasi dini diperlukan sebagai dasar pemerolehan berliterasi tahap selanjutnya. Komponen literasi tersebut dijelaskan sebagai berikut: (1) Literasi Dini (Early Literacy), yaitu kemampuan untuk menyimak, memahami bahasa lisan, dan berkomunikasi melalui gambar dan lisan yang dibentuk oleh pengalamannya berinteraksi dengan lingkungan sosialnya di rumah. Pengalaman peserta didik dalam berkomunikasi dengan bahasa ibu menjadi fondasi perkembangan literasi dasar. (2) Literasi Dasar (Basic Literacy), yaitu kemampuan untuk mendengarkan, berbicara, membaca, menulis, dan menghitung (counting) berkaitan dengan kemampuan analisis untuk memperhitungkan (calculating), mempersepsikan informasi (perceiving), mengomunikasikan, serta menggambarkan informasi (drawing) berdasarkan pemahaman dan pengambilan kesimpulan pribadi. (3) Literasi Perpustakaan (Library Literacy), antara lain, memberikan pemahaman cara membedakan bacaan fiksi dan nonfiksi, memanfaatkan koleksi referensi dan 
periodikal, memahami Dewey Decimal System sebagai klasifikasi pengetahuan yang memudahkan dalam menggunakan perpustakaan, memahami penggunaan katalog dan pengindeksan, hingga memiliki pengetahuan dalam memahami informasi ketika sedang menyelesaikan sebuah tulisan, penelitian, pekerjaan, atau mengatasi masalah. (4) Literasi Media (Media Literacy), yaitu kemampuan untuk mengetahui berbagai bentuk media yang berbeda, seperti media cetak, media elektronik (media radio, media televisi), media digital (media internet), dan memahami tujuan penggunaannya. (5) Literasi Teknologi (Technology Literacy), yaitu kemampuan memahami kelengkapan yang mengikuti teknologi seperti peranti keras (hardware), peranti lunak (software), serta etika dan etiket dalam memanfaatkan teknologi. Berikutnya, kemampuan dalam memahami teknologi untuk mencetak, mempresentasikan, dan mengakses internet. Dalam praktiknya, juga pemahaman menggunakan komputer (Computer Literacy) yang di dalamnya mencakup menghidupkan dan mematikan komputer, menyimpan dan mengelola data, serta mengoperasikan program perangkat lunak. Sejalan dengan membanjirnya informasi karena perkembangan teknologi saat ini, diperlukan pemahaman yang baik dalam mengelola informasi yang dibutuhkan masyarakat. (6) Literasi Visual (Visual Literacy), adalah pemahaman tingkat lanjut antara literasi media dan literasi teknologi, yang mengembangkan kemampuan dan kebutuhan belajar dengan memanfaatkan materi visual dan audiovisual secara kritis dan bermartabat. Tafsir terhadap materi visual yang tidak terbendung, baik dalam bentuk cetak, auditori, maupun digital (perpaduan ketiganya disebut teks multimodal), perlu dikelola dengan baik. Bagaimanapun di dalamnya banyak manipulasi dan hiburan yang benarbenar perlu disaring berdasarkan etika dan kepatutan (Dirjen Pendidikan Dasar dan Menengah, 2016); (Teguh, 2017); (Kebudayaan, 2016).

\section{Prinsip-prinsip Literasi Sekolah}

Praktik-praktik yang baik dalam gerakan literasi sekolah menekankan prinsip-prinsip sebagai berikut: (1) Perkembangan literasi berjalan sesuai tahap perkembangan yang dapat diprediksi. (2) Tahap perkembangan anak dalam belajar membaca dan menulis saling beririsan antartahap perkembangan. Memahami tahap perkembangan literasi peserta didik dapat membantu sekolah untuk memilih strategi pembiasaan dan pembelajaran literasi yang tepat sesuai kebutuhan perkembangan mereka. (3) Program literasi yang baik bersifat berimbang. Sekolah yang menerapkan program literasi berimbang menyadari bahwa tiap peserta didik memiliki kebutuhan yang berbeda. Oleh karena itu, strategi membaca dan jenis teks yang dibaca perlu divariasikan dan disesuaikan dengan jenjang pendidikan. Program literasi yang bermakna dapat dilakukan dengan memanfaatkan bahan bacaan kaya ragam teks, seperti karya sastra untuk anak dan remaja. (4) Program literasi terintegrasi dengan kurikulum. Pembiasaan dan pembelajaran literasi di sekolah adalah tanggung jawab semua guru di semua mata pelajaran sebab pembelajaran mata pelajaran apapun membutuhkan bahasa, terutama membaca dan menulis. Dengan demikian, pengembangan profesional guru dalam hal literasi perlu diberikan kepada guru semua mata pelajaran. (5) Kegiatan membaca dan menulis dilakukan kapanpun. Misalnya, 'menulis surat kepada presiden' atau 'membaca untuk ibu' merupakan contoh-contoh kegiatan literasi yang bermakna. (6) Kegiatan literasi mengembangkan budaya lisan. Kelas berbasis literasi yang kuat diharapkan memunculkan berbagai kegiatan lisan berupa diskusi tentang 
buku selama pembelajaran di kelas. Kegiatan diskusi ini juga perlu membuka kemungkinan untuk perbedaan pendapat agar kemampuan berpikir kritis dapat diasah. Peserta didik perlu belajar untuk menyampaikan perasaan dan pendapatnya, saling mendengarkan, dan menghormati perbedaan pandangan. (7) Kegiatan literasi perlu mengembangkan kesadaran terhadap keberagaman. Warga sekolah perlu menghargai perbedaan melalui kegiatan literasi di sekolah. Bahan bacaan untuk peserta didik perlu merefleksikan kekayaan budaya Indonesia agar mereka dapat terpajan pada pengalaman multicultural (Dirjen Pendidikan Dasar dan Menengah, 2016); (Kebudayaan, 2016).

\section{E. Strategi Membangun Budaya Literasi Sekolah}

Agar sekolah mampu menjadi garis depan dalam pengembangan budaya literasi, Beers, dkk. (2009) dalam buku $A$ Principal's Guide to Literacy Instruction, menyampaikan beberapa strategi untuk menciptakan budaya literasi yang positif di sekolah : (1) Mengkondisikan lingkungan fisik ramah literasi. (2) Mengupayakan lingkungan sosial dan afektif sebagai model komunikasi dan interaksi yang literat. (3) Mengupayakan sekolah sebagai lingkungan akademik yang literat. Untuk lebih jelasnya, perhatikan beberapa parameter yang dapat digunakan sekolah untuk membangun budaya literasi sekolah yang baik (Kebudayaan, 2016); (Dirjen Pendidikan Dasar dan Menengah, 2016).

Tabel 1. Parameter Untuk Membangun Budaya Literasi Sekolah

\begin{tabular}{l}
\hline L. Lingkungan Fisik \\
Karya peserta didik dipajang di \\
sepanjang lingkungan sekolah, termasuk \\
koridor dan kantor (kepala sekolah, \\
guru, administrasi, bimbingan \\
konseling). \\
$\begin{array}{l}\text { Karya peserta didik dirotasi secara } \\
\text { berkala untuk memberi kesempatan }\end{array}$
\end{tabular}

yang seimbang kepada semua peserta didik.

Buku dan materi bacaan lain tersedia di pojok-pojok baca di semua ruang kelas.

Buku dan materi bacaan lain tersedia juga untuk peserta didik dan orang tua/pengunjung di kantor dan ruangan selain ruang kelas.

Kantor kepala sekolah memajang karya peserta didik dan buku bacaan untuk anak.

Kepala sekolah bersedia berdialog bersama warga sekolah

b. Lingkungan Sosial dan Afektif

Penghargaan terhadap prestasi peserta didik (akademik dan nonakademik) diberikan secara rutin (tiap minggu/bulan). Upacara hari Senin merupakan salah satu kesempatan yang tepat untuk pemberian penghargaan mingguan.

Kepala sekolah terlibat aktif dalam pengembangan literasi.

Merayakan hari-hari besar dan nasional dengan nuansa literasi, misalnya merayakan Hari Kartini dengan membaca surat-suratnya.

Terdapat budaya kolaborasi antara guru dan staf dengan mengakui kepakaran masing-masing.

Terdapat waktu yang memadai bagi staf untuk berkolaborasi dalam menjalankan program literasi dan hal-hal yang terkait dengan pelaksanaannya.

Staf sekolah dilibatkan dalam proses pengambilan keputusan, terutama dalam menjalankan program literasi.

c. Lingkungan Akademik

Terdapat TLS (Tim Literasi Sekolah) yang bertugas melakukan asesmen dan perencanaan. Bila diperlukan, ada pendampingan dari pihak eksternal.

Disediakan waktu khusus dan cukup banyak untuk pembelajaran dan pembiasaan literasi: membaca dalam hati (sustained silent reading), membacakan buku dengan nyaring (reading aloud), membaca bersama, 
(shared reading), membaca terpandu (guided reading), diskusi buku, bedah buku, presentasi (show-and-tell presentation).

Waktu berkegiatan literasi di jaga agar tidak dikorbankan untuk kepentingan lain.

Disepakati waktu berkala untuk TLS membahas pelaksanaan gerakan literasi.

Buku fiksi dan nonfiksi tersedia dalam jumlah cukup banyak di sekolah. Buku cerita fiksi sama pentingnya dengan buku berbasis ilmu pengetahuan.

Ada beberapa buku wajib dibaca oleh warga sekolah.

Ada kesempatan pengembangan professional tentang literasi yang diberikan untuk staf, melalui kerjasama dengan institusi terkait (perguruan tinggi, dinas pendidikan, dinas perpustakaan, atau berbagi pengalaman dengan sekolah lain)

Seluruh warga antusias menjalankan program literasi, engan tujuan membangun organisasi sekolah yang suka belajar.

(Dirjen Pendidikan Dasar dan Menengah, 2016); (Kebudayaan, 2016)

\section{F. Tahap Pelaksanaan Gerakan Literasi Sekolah}

Pelaksanaan Gerakan Literasi

Sekolah memiliki tiga tahapan yaitu, pembiasaan, pengembangan, dan pembelajaran. Prinsip-prinsip kegiatan membaca di dalam tahap pembiasaan dipaparkan berikut ini. (1) Guru menetapkan waktu 15 menit membaca setiap hari. Sekolah bisa memilih menjadwalkan waktu membaca di awal, tengah, atau akhir pelajaran, bergantung pada jadwal dan kondisi sekolah masingmasing. Kegiatan membaca dalam waktu pendek, namun sering dan berkala lebih efektif daripada satu waktu yang panjang namun jarang (misalnya $1 \mathrm{jam} / \mathrm{minggu}$ pada hari tertentu). (2) Buku yang dibaca/dibacakan adalah buku nonpelajaran. (3) Peserta didik dapat diminta membawa bukunya sendiri dari rumah. (4) Buku yang dibaca/dibacakan adalah pilihan peserta didik sesuai minat dan kesenangannya. (5) Kegiatan membaca/membacakan buku di tahap ini tidak diikuti oleh tugastugas yang bersifat tagihan/penilaian. (6) Kegiatan membaca/membacakan buku di tahap ini dapat diikuti oleh diskusi informal tentang buku yang dibaca/dibacakan. Meskipun begitu, tanggapan peserta didik bersifat opsional dan tidak dinilai. (7) Kegiatan membaca/membacakan buku di tahap ini berlangsung dalam suasana yang santai, tenang, dan menyenangkan. Suasana ini dapat dibangun melalui pengaturan tempat duduk, pencahayaan yang cukup terang dan nyaman untuk membaca, poster-poster tentang pentingnya membaca. (8) Dalam kegiatan membaca dalam hati, guru sebagai pendidik juga ikut membaca buku selama 15 menit.

2. Pengembangan. Meningkatkan kemampuan literasi melalui kegiatan menanggapi buku pengayaan.

Pada prinsipnya, kegiatan literasi pada tahap pengembangan sama dengan kegiatan pada tahap pembiasaan. Yang membedakan adalah bahwa kegiatan 15 menit membaca diikuti oleh kegiatan tindak lanjut pada tahap pengembangan. Dalam tahap pengembangan, peserta didik didorong untuk menunjukkan keterlibatan pikiran dan emosinya dengan proses membaca melalui kegiatan produktif secara lisan maupun tulisan. Perlu dipahami bahwa kegiatan produktif ini tidak dinilai secara akademik. Mengingat kegiatan tindak lanjut memerlukan waktu tambahan di luar 15 menit membaca, sekolah didorong untuk memasukkan waktu literasi dalam jadwal pelajaran sebagai kegiatan membaca mandiri atau sebagai bagian dari kegiatan kokurikuler. Bentuk, frekuensi, dan durasi pelaksanaan kegiatan tindak lanjut disesuaikan dengan kondisi masingmasing sekolah. 
Tujuan Kegiatan Literasi di Tahap Pengembangan. Sebagai tindak lanjut dari kegiatan di tahap pembiasaan, kegiatan 15 menit membaca di tahap pengembangan diperkuat oleh berbagai kegiatan tindak lanjut yang bertujuan untuk: (1) Mengasah kemampuan peserta didik dalam menanggapi buku pengayaan secara lisan dan tulisan; (2) Membangun interaksi antarpeserta didik dan antara peserta didik dengan guru tentang buku yang dibaca; (3) Mengasah kemampuan peserta didik untuk berpikir kritis, analitis, kreatif, dan inovatif; dan (4) Mendorong peserta didik untuk selalu mencari keterkaitan antara buku yang dibaca dengan diri sendiri dan lingkungan sekitarnya.

Prinsip-prinsip Kegiatan Literasi di Tahap Pengembangan. Dalam melaksanakan kegiatan tindak lanjut, beberapa prinsip yang perlu dipertimbangkan dipaparkan sebagai berikut : (1) Buku yang dibaca/dibacakan adalah buku selain buku teks pelajaran. Buku yang dibaca/ dibacakan adalah buku yang diminati oleh peserta didik. Peserta didik diperkenankan untuk membaca buku yang dibawa dari rumah. (2) Kegiatan membaca/membacakan buku di tahap ini dapat diikuti oleh tugas-tugas presentasi singkat, menulis sederhana, presentasi sederhana, kriya, atau seni peran untuk menanggapi bacaan, yang disesuaikan dengan jenjang dan kemampuan peserta didik. (3) Tugastugas presentasi, menulis, kriya, atau seni peran dapat dinilai secara nonakademik dengan fokus pada sikap peserta didik selama kegiatan. Tugas-tugas yang sama nantinya dapat dikembangkan menjadi bagian dari penilaian akademik bila kelas /sekolah sudah siap mengembangkan kegiatan literasi ke tahap pembelajaran. (4) Kegiatan membaca/membacakan buku berlangsung dalam suasana yang menyenangkan. Untuk memberikan motivasi kepada peserta didik, guru sebaiknya memberikan masukan dan komentar sebagai bentuk apresiasi. (5) Terbentuknya Tim Literasi Sekolah (TLS). Untuk menunjang keterlaksanaan berbagai kegiatan tindak lanjut GLS di tahap pengembangan ini, sekolah sebaiknya membentuk TLS, yang bertugas untuk merancang, mengelola, dan mengevaluasi program literasi sekolah. Pembentukan TLS dapat dilakukan oleh kepala sekolah. Adapun TLS beranggotakan guru (sebaiknya guru bahasa atau guru yang tertarik dan berlibat dengan masalah literasi) serta tenaga kependidikan atau pustakawan sekolah.

3. Pembelajaran. Meningkatkan kemampuan literasi di semua mata pelajaran: menggunakan buku pengayaan dan strategi membaca di semua mata pelajaran. Tujuan Kegiatan Literasi di Tahap Pembelajaran : (1) Mengembangkan kemampuan memahami teks dan mengaitkannya dengan pengalaman pribadi sehingga terbentuk pribadi pembelajar sepanjang hayat; (2) Mengembangkan kemampuan berpikir kritis; dan (3) Mengolah dan mengelola kemampuan komunikasi secara kreatif (verbal, tulisan, visual, digital) melalui kegiatan menanggapi teks buku bacaan dan buku pelajaran.

Prinsip-prinsip Kegiatan Literasi di Tahap Pembelajaran. Kegiatan pada tahap ini dilakukan untuk mendukung pelaksanaan Kurikulum 2013 yang mensyaratkan peserta didik membaca buku nonteks pelajaran. Beberapa prinsip yang perlu dipertimbangkan dalam tahap pembelajaran ini, antara lain: buku yang dibaca berupa buku tentang pengetahuan umum, kegemaran, minat khusus, atau teks multimodal, dan juga dapat dikaitkan dengan mata pelajaran tertentu; dan ada tagihan yang sifatnya akademis (terkait dengan mata pelajaran) (Dirjen Pendidikan Dasar dan Menengah, 2016).

METODE PELAKSANAAN 
Kegiatan pengabdian masyarakat ini dilaksanakan melalui tahapan atau langkah-langkah sebagai berikut : (1) Observasi ke lapangan mencari data tentang permasalahan pendidikan di desa Sawarna, Lebak banten. (2) Melakukan Pelatihan kepada Siswa/i SD di Sawarna Lebak, Banten dengan metode nonton Video, ceramah, Games, dll. (3) Setelah dilakukan pelatihan maka sekaligus akan dilakukan evaluasi pelaksanaan program dan keberlanjutan program di lapangan setelah kegiatan PPM selesai dilaksanakan.

\section{HASIL DAN PEMBAHASAN}

Kegiatan pengabdian masyarakat ini dilakukan di TK PGRI di pesisir Pantai Sawarna Lebak Banten mengenai sosialisasi literasi membaca pada anakanak di pesisir pantai Sawarna. Kegiatan ini bertujuan agar anak-anak dapat termotivasi untuk membaca dan berani berbicara serta berani mengeluarkan pendapatnya baik di kelas maupun di ruang publik. Pelatihan ini diharapkan dapat memberikan inspirasi dan membawa perubahan bagi masyarakat khususnya anak-anak di desa Sawarna.

Acara kegiatan pengabdian masyarakat ini dilaksanakan pada : Hari/Tanggal : Selasa, 13 Februari 2018; Pukul : 08.00-10.00 WIB; Tempat : TK. PGRI Sawarna. Peserta terdiri dari 35 Siswa TK (Daftar Hadir Terlampir). Acara dihadiri oleh : (1) Ibu Nunung (Kepala Sekolah TK PGRI); (2) Ibu Siti (Guru TK PGRI). Susunan Acara : Menyanyikan Lagu Indonesia Raya; Menyanyikan Lagu mars TK PGRI; Sambutan Ibu Nunung (Kepala Sekolah TK. PGRI); Pemberian Materi dengan nara sumber : Dr. Suraya. Acara ditutup oleh Ibu Nunung

Pemberian Materi di awal dengan melakukan pretest kepada anak-anak. Hasilnya sebagai berikut :

\begin{tabular}{|l|l|l|}
\hline No. & PERTANYAAN & JAWABAN \\
\hline 1 & Apakah orang tua & Hanya \\
\hline
\end{tabular}

\begin{tabular}{|l|l|l|}
\hline & $\begin{array}{l}\text { suka bercerita } \\
\text { atau } \\
\text { mendongeng? }\end{array}$ & $\begin{array}{l}\text { beberapa yang } \\
\text { menjawab } \\
\text { IYA, } \\
\text { selebihnya } \\
\text { hanya diam } \\
\text { saja }\end{array}$ \\
\hline 2 & $\begin{array}{l}\text { Siapakah yang } \\
\text { suka bercerita } \\
\text { atau mendongeng }\end{array}$ & $\begin{array}{l}\text { Kebanyakan } \\
\text { menjawab Ibu } \\
\text { atau Mama }\end{array}$ \\
\hline 3 & $\begin{array}{l}\text { Dongeng atau } \\
\text { cerita apa yang } \\
\text { biasanya di } \\
\text { ceritakan }\end{array}$ & $\begin{array}{l}\text { 1. Malin } \\
\text { Kundang } \\
\text { 2. Sinderela } \\
\text { 3. Saijah dan } \\
\text { Adinda } \\
\text { 4. Si Kancil } \\
\text { 5asulullah } \\
\text { Muhammad } \\
\text { SAW }\end{array}$ \\
\hline 4. & $\begin{array}{l}\text { Apakah dirumah } \\
\text { ada buku-buku } \\
\text { cerita? }\end{array}$ & $\begin{array}{l}\text { Hanya } \\
\text { beberapa yang } \\
\text { menjawab, } \\
\text { selebihnya } \\
\text { hanya diam }\end{array}$ \\
\hline 5 & $\begin{array}{l}\text { Siapa yang } \\
\text { mengajarkan } \\
\text { membaca }\end{array}$ & $\begin{array}{l}\text { Seluruhnya } \\
\text { menjawab "Ibu } \\
\text { Guru" }\end{array}$ \\
\hline
\end{tabular}

Berdasarkan hasil pretest di atas, ternyata kebiasaan bercerita dan membaca anak-anak di daerah pesisir pantai Sawarna Lebak Banten masih rendah. Anak-anak tersebut sangat semangat untuk belajar, menulis, membaca bahkan bernyanyi. Di Sekolah Taman KanakKanak lah tempat dimana anak-anak bisa belajar sambil bermain.

Pada awalnya, menurut keterangan $\mathrm{Bu}$ Nunung (Kepala Sekolah) ketika membuka TK PGRI, banyak orang tua yang belum mau mensekolahkan anakanaknya di TK, walaupun saat itu untuk masuk sekolah TK gratis, tidak ada biaya. Namun akhirnya seiring dengan berjalannya waktu sedikit demi sedikit sudah banyak orang tua yang mensekolahkan anak-anaknya di TK PGRI. $\mathrm{Bu}$ Nunung juga gigih mempromosikan TK PGRI-nya kepada 
para orang tua di sekitar Pesisir Pantai Sawarna. Selain sebagai guru dan kepala Skeolah TK, Bu Nunung juga membuka toko Pakaian Pantai di Pantai Tanjung Selayar, Sawarna, Lebak Banten. Sehingga bisa lebih banyak bertemu dengan orang-orang atau masyarakat di pantai pesisir Sawarna.

Pada kegiatan pelatihan ini, anakanak terlihat antusias karena selain bertemu dengan orang baru, juga mendapatkan sesuatu yang baru. Nara sumber atau pemateri mengawali dengan sedikit bertanya mengenai latar belakang pengetahuan tentang membaca dan bercerita. Setelah itu mengajak anak-anak bernyanyi beberapa lagu anak-anak. Materi dimulai dengan metode story telling tentang Si Kancil, Tom and Jery dan cerita Saijah dan adinda. Dilajutkan dengan mengajukan teka-teki berhadiah. Sebelum ditutup pemateri memutar Video tentang cerita Timun Mas. Sehingga suasana menjadi meriah dan komunikasi yang terjalin menjadi akrab. Acara ditutup dengan bernyayi bersama-sama kembali.

Acara kegiatan pengabdian kepada masyarakat di TKJ PGRI ini ditutup oleh Ibu Nunung, selaku kapala sekolah TK PGRI dan dilanjutkan dengan Foto Bersama.

Hasil kegiatan pengabdian kepada masyarakat ini secara garis besar dapat dibahas dalam beberapa aspek : target peserta, tujuan kegiatan pengabdian masyarakat, materi pelatihan serta kepuasan peserta.

Dari segi target peserta, jumlah peserta yang ditargetkan adalah 20 orang siswayang diharapkan dapat menjadi agent of change yang dapat bercerita kepada kepada teman-teman lainnya mengenai materi yang mereka dapatkan. Target ini tercapai dan justru melebihi jumlah yang telah direncanakan sebelumnya. Peserta yang datang berjumlah 35 siswa/i.
Dari antuisiasme peserta saat mengikuti acara, terlihat bahwa anak-anak terlihat ceria dan gembira bahkan selalu mengikuti bernyanyi dan antusias menjawab setiap pertanyaan kuiz dan games yang diberikan. Terlebih lagi mereka antusias menonton video yang diputar pemateri.

Dari segi materi, bahan yang disampaikan memang begitu mengena dengan kebutuhan siswa/i. setiap pertanyaan yang diajukan juga dapat dijawab dengan detail dan menyeluruh oleh pembicara. Sehingga, pertanyaanpertanyaan yang diajukan seluruhnya dapat terjawab sesuai dengan kebutuhan peserta.

Terakhir ditinjau dari kepuasan peserta kegiatan pengabdian dapat dikatakan sangat baik. Hal ini dapat dilihat dari respon yang mengatakan bahwa materi yang disampaikan sesuai dengan yang dibutuhkan oleh peserta didiknya, selain itu dia juga mengikuti kegiatan dari awal hingga akhir. Selain itu dari segi peserta, terlihat dari sikap mereka yang kooperatif dan feedback yang relevan dengan apa yang disampaikan oleh pemateri.

\section{SIMPULAN}

Para peserta belum sepenuhnya memiliki kebiasaan membaca baik di rumah maupun di sekolah. Minimnya fasilitas buku-buku cerita anak-anak yang dimiliki sekolah maupun di rumah. Anak-anak atau Siswa/i TK membutuhkan motivasi dan inspirasi mengenai kegiatan dan pembiasaan membaca atau literasi membaca.

Kegiatan pengabdian masyarakat serupa agar terus dipertahankan dan diperluas jangkauannya, agar semakin banyak anak-anak yang memiliki kebiasaan membaca. Membantu dan mendukung adanya fasilitas buku-buku dan alat-alat tulis untuk mndukung gerakan literasi membaca di sekolah. 


\section{DAFTAR PUSTAKA}

Rahman, S. (2017). Membangun Budaya Membaca pada anak Melalui Program Gerakan Literasi Seko,ah. Terampil : Jurnal Pendidikan dan Pembelajaran dasar , 4 (1), 151-174.

Teguh, M. (15. Maret 2017). Gerakan Literasi Sekolah dasar. Prosiding Seminar Nasional Aktualisasi Kurikulu 2013 di Sekokah dasar melalui Gerakan Literasi Sekolah untuk Menyiapkan Generasi Unggul dan Berbudi Pekerti, 18-26.

Dirjen Pendidikan Dasar dan Menengah, K. P. (2016). Panduan Gerakan Literasi Sekolah di Sekolah Dasar (Bd. 1). Jakarta, DKI Jakarta, Indonesia: Dirjen Pendidikan Dasar dan Menengah, Kementrian Pendidikan dan Kebudayaan.

Kebudayaan, D. P. (2016). Desain Induk Gerakan Literasi Sekolah (Bd. 1). Jakarta, DKI Jakarta, Indonesia: Dirjen Pendidikan Dasar dan Menengah, Kementrian Pendidikan dan Kebudayaan.

KPAI.go.id. (25. Januari 2018). KPAI.go.id. Abgerufen am 3. Februari 2018 von
KPAI.go.id:

http://www.kpai.go.id/berita/kpaidesak-pemerintah-bangun-sekolahdarurat-di-lebak-banten/

Tirtayasa, P. (2. Mei 2016). bantenday.com. Abgerufen am 20. Desember 2017 von bantenday.com:

https://bantenday.com/pandji-tirtayasadeklarasikan-budaya-membaca/

Adrian. (6. Oktober 2017).

Channelbanten.com. Abgerufen am 26. Desember 2017 von Channelbanten.com: https://www.chanelbanten.com/2017/1 0/06/ini-kisah-guru-paud-yang-pernahdiusir-gara-gara-numpang-belajar/

Tirto.id. (2016). tirto.id. Abgerufen am 20. desember 2017 von tirto.id: https://tirto.id/tingkat-literasi-anakmuda-asia-bHFT

Maulipaksi, D. (18. Agustus 2015). Kemendikbud.go.id. Abgerufen am 20. Desember 2017 von Kemendikbud.go.id: https://www.kemdikbud.go.id/main/blo g/2015/08/mendikbud-luncurkangerakan-literasi-sekolah-4514-45144514 